\title{
THE TENDENCY OF ENGLISH TEACHERS IN TEACHING GRAMMAR FOR YOUNG LEARNERS
}

\author{
Maria Setyaningsih Nernere \\ (Universitas Atma Jaya Yogyakarta/ maria_setyaningsih@staff.uajy.ac.id)
}

\begin{abstract}
Many language practitioners believe in the importance of grammar teaching for young learners as it supports the basic for young learners' language development. Various beliefs on the grammar teaching method are aroused too. It leads to confusion on how to teach grammar in young learners' classroom. Thus, this paper aims to investigate further how grammar is taught in young learners' classroom. After having observations in sixth-graders' English classes and deep interviews with the teachers who were observed, it is found that the teachers tended to teach grammar explicitly. It happened as they believed in the urgency of grammar mastery in the early ages. Moreover, they consider the students as those who are ready enough to understand the grammar rule as their logic is considered more advanced than their junior in school. This finding can be a means of supporting teachers' self-evaluation, schools' evaluation and also for other educational practitioners who want to investigate teaching grammar for young learners further.
\end{abstract}

Keywords:

Tendency; English Teacher; Grammar Teaching; Young Learners

DOI: $10.19105 /$ ojbs.v13i2.2254

\section{A. Introduction}

Nowadays, although English is not included in the applied curriculum anymore, many Elementary schools in Indonesia still have English in class. For the success of English class, many components have been the concern of the English practitioners including grammar teaching. According to Cameron, grammar is necessary to express precise meanings in discourse. ${ }^{1}$ By having good grammar, the language can be communicated more effectively.

${ }^{1}$ Lynne Cameron, Teaching Languages to Young Learners (Cambridge: Cambridge University Press, 2001).
In young learners' classroom, giving grammar understanding is very important. Garrett says that it is crucial for the development of the learners' language ability in their early stages. ${ }^{2}$ By introducing grammar to young learners earlier, their grammar-conscious awareness can be strongly developed ${ }^{2}$. It affects positively to their systematic language production. Once they communicate, they will be aware of producing the language. They may make

\footnotetext{
${ }^{2}$ Lisa Garrett, 'Teaching Grammar in an English as a Foreign Language (Efl) Context', The Australian Journal of Indigenous Education 31 (2003): 35-40, https://doi.org/10.1017/S1326011100003677.
} 
mistake but they will have the courage to revise it as they realize that it is grammatically wrong. If grammar is taught from the early stage, children may have little possibility of making grammatical mistakes so their language spoken can be clear and understandable. According to Brown, grammar is needed to produce clear and effective communication ${ }^{3}$ and supported by Sitorus who says that without recognizing the grammatical rules, the language that people produce will simply be chaotic. ${ }^{4}$ As a result, they might be not used to produce the language effectively and efficiently. Therefore, some parties believe that grammar is better to be introduced to young learners.

On the other hand, other practitioners find that grammar is not a good idea to be taught in young learners' classroom. Brown assumes if the grammar is taught as the main focus for classwork in young learners' classroom, it may block the acquisition of fluency acquisition. ${ }^{5}$ Students being too focused on the grammar rule while producing the language may feel difficult to express their mind freely. Therefore, Pinter suggests avoiding explicit grammar teaching method as he finds that

\footnotetext{
${ }^{3} \mathrm{H}$. Douglas Brown, Teaching by Principles: An Interactive Approach to Language Pedagogy, 2nd ed. (San Fransisco: Longman, 2007).

${ }^{4}$ Deborah Sitorus, Teaching Grammar to Young Learners (Jakarta: Universitas Pendidikan Indonesia, 2016).

${ }^{5}$ Brown, Teaching by Principles: An Interactive Approach to Language Pedagogy.
}

teaching grammar in isolation can be a dry and boring activity. ${ }^{6}$ If grammar is taught explicitly, the students learn the grammar in separated session. The other version is implicit grammar teaching method. Brown defines implicit learning as learning without conscious attention or awareness. ${ }^{7}$ Therefore, the students will learn grammar without noticing that they are learning grammar as they focus more on acquiring the language exposed to them. Considering these two versions of grammar teaching method, Uysal \& Bardakci also support that grammar should be taught implicitly. ${ }^{8}$ According to Ibrahim, it can be done by using the language to learn grammar, not learning the grammar to use the language. ${ }^{9}$ By doing so, young learners' language acquisition can be developed better without being hindered by grammar exposure.

Another important issue to notice on teaching grammar for young learners is that young learners have special characteristics compared to people from other levels of ages. Moon states that

\footnotetext{
6 Annamaria Pinter, Children Learning Second Languages (London: Palgrave Macmillan, 2011).

7 Brown, Teaching by Principles: An Interactive Approach to Language Pedagogy.

8 Hacer Hande Uysal, Mehmet Bardakci, and Gaziantep University, 'Teacher Beliefs and Practices of Grammar Teaching: Focusing on Meaning, Form, or Forms?', South African Journal of Education 34, no. 1 (5 February 2014): 1-16, https://doi.org/10.15700/201412120943.

${ }^{9}$ Nelvia Ibrahim, 'Games For Teaching Grammar To Young Learners', Indonesian Journal of Integrated English Language Teaching 2, no. 1 (2016): 49-63, http://dx.doi.org/10.24014/ijielt.v2i1.2366.
} 
young learners are those who will learn only if they are engaged in an interesting activity which is fun yet meaningful. ${ }^{10}$ If grammar teaching is considered as a burdened and boring activity, it might not work for young learners. To make the learning works and meaningful to young learners, the learning should be adapted based on their characteristics. Moon states that young learners tend to go for meaning. They are experts on guessing meaning even if they do not understand individual words. ${ }^{11}$ Moreover, Harmer argues that they can respond to it once they can grasp the meaning. ${ }^{12}$ Unfortunately, teachers often ask their students to make sure that they understand. If young learners do not find it meaningful, they will not be active as planned and the goal of teaching and learning may not be accomplished.

Besides, young learners have a short span of attention. It is easy for them to get bored and feel demotivated if their learning is difficult, not interesting and not meaningful to them. Moreover, what they learn is different from their mother tongue. Moon assures that the bored and demotivated young learners will not succeed in learning. As they tend to react based on their feelings. ${ }^{13}$ If they are demotivated because of experiencing a difficult situation, they will end up hating to learn English. It will give

\footnotetext{
10 Jayne Moon, Children Learning Eng (Oxford: Macmillan Henneiman, 2000).

${ }^{11}$ Moon.

12 Jeremy Harmer, How to Teach English (London: Pearson Education Limited, 2007).

${ }^{13}$ Moon, Children Learning Eng.
}

bad impact on their English ability in the future. Thus, the teacher should design the learning that is not burdening for them.

Harmer states that students often learn indirectly rather than learn directly. ${ }^{14}$ Thus, the more meaningful the learning they experience, the more knowledge they gain. Reflecting on those characteristics, Cameron suggests that the teachers of young learners should provide physical activities which deal with routines and repetition in learning. ${ }^{15}$ Besides, Pinter states that full of gesture, intonation, demonstration, action, and facial expressions to convey meaning are also needed to concern. ${ }^{16}$ Additionally, Cameron also states that providing authentic ready-made bits of language such as songs, rhymes, drama, etc., and do scaffolding can also be listed as teachers' option to develop in class. ${ }^{17}$ It has also been proved by Hasanah as she recommends having fun grammar teaching ways such as using people pictures, creating captions, cut- off stories, partial pictures and picture dictation for the success of grammar teaching. ${ }^{18}$ Therefore, the teaching grammar method should not be

\footnotetext{
${ }^{14}$ Harmer, How to Teach English.

15 Cameron, Teaching Languages to Young Learners.

${ }_{17}^{16}$ Pinter, Children Learning Second Languages.

17 Cameron, Teaching Languages to Young Learners.

${ }^{18}$ Henny Uswatun Hasanah, 'Teaching Grammar Using Pictures', OKARA: Jurnal Bahasa Dan Sastra 9, no. 1 (2015): 103-12, https://doi.org/http:dx.doi.org/10.19105/ojbs.v9i1.5 83.
} 
direct teaching only but it should also involve activities accommodating the young learners' special characteristics.

This fact has been a concern for those who have an interest in researching teaching English for young learners. In one hand, teaching grammar explicitly is good to develop the grammar consciousness of the learners so in the future they can have the awareness on grammar mistakes. Uysal \& Bardakci find that teachers predominantly prefer to teach grammar explicitly or to use focus on form approach. ${ }^{19}$ On the other hand, some find that it affects badly on young learners' language acquisition. Ibrahim assumes that in young learners' class, teaching grammar must be taught in different ways, not in an explicit way. ${ }^{20}$ It has been also supported by Sitorus who suggests avoiding to use metalanguage (e.g. passive verb, subject, object) and focus instead on what grammar can do to achieve communication. ${ }^{21}$ Meanwhile, Garrett suggests a combination of both explicit and implicit way to teach grammar as an effective method to promote independent language acquisition. ${ }^{22}$ They find that teaching English to young learners is very different from teaching adults, including treatment for grammar

19 Uysal, Bardakci, and Gaziantep University, 'Teacher Beliefs and Practices of Grammar Teaching'.

20 Ibrahim, 'Games For Teaching Grammar To Young Learners'.

${ }^{21}$ Sitorus, Teaching Grammar to Young Learners.

22 Garrett, 'Teaching Grammar in an English as a Foreign Language (Efl) Context'. teaching. From these various perceptions, it can be seen that there are still pro and contra related to the most effective way to teach grammar for young learners.

Having various beliefs on grammar teaching methods may result in confusion that may hinder the success of language learning. Hence, this paper aims to investigate the facts of grammar teaching happening in the real young learners' classroom. Here the setting is focused on six graders' class. In elementary school, six graders are considered as an advanced one compared to the lower grades in primary schools. Some say that six graders are ready enough to have explicit grammar learning. While others still consider them as young learners who may have difficulty in processing explicit grammar learning. These two perspective leads to curiosity on how the teacher treats them in grammar learning.

Another curiosity is whether the English teachers apply grammar teaching while considering the young learners' class principles. One of the principles is the important role of teaching resources for the success of grammar teaching in young learners' class as stated by Ummah. ${ }^{23}$ Therefore, this paper will analyze how teaching grammar is done in six graders. It is expected that this investigation can

\footnotetext{
${ }^{23} \mathrm{~S}$ Sumihatul Ummah, 'The Effective Teaching Grammar Activities with No Resources', OKARA: Jurnal Bahasa Dan Sastra 7, no. 2 (2013): 14, http://dx.doi.org/10.19105/ojbs.v7i2.446.
} 
result in the real description of grammar teaching in young learners. Later, it can be reflected whether it is in line with the principles of grammar teaching and young learners' characteristics.

\section{B. Method}

This study is qualitative research aimed to investigate the grammar teaching in a six graders' classroom. The setting chosen is in schools that still have English listed in their curriculum. There were two data collecting methods done in this research. First is class observation equipped by observation notes and audio recorder. According to Ary et al., observation notes would cover the comprehensive picture of a situation which was observed. ${ }^{24}$ In fact, investigating teachers' belief using direct observation was not enough yet. To find the details on why the grammar teaching was done that way, a depth interview was used as the second data collecting method. The interviewees were English teachers teaching the observed class. They have met the criteria of having experiences of teaching English in Elementary school for more than five years and having English education as their educational background.

Besides aiming to achieve the trustworthiness of data, the interviews were also done to confirm the results of the analysis. After having sufficient data, the analysis was presented and discussed

${ }^{24}$ Donald Ary et al., Introduction to Research in Education, 10th ed. (Boston: Cengage Learning, 2018). with the teacher in the interview. As a result, the discussion was presented with the teachers' confirmation.

\section{Results}

\section{The Position of Grammar in Teaching Young Learners}

Based on the observation, the teachers emphasized the urgency of grammar learning for the sixth graders' English class. Before the activity of practicing language skill, a teacher even advised the students to pay attention to the grammar explanation and asked them not to take notes first. She started explaining the grammar in class and gave written exercises to the students. It seemed that grammar had been a burden for the learners. At the end of the grammar explanation, they still did not understand and requested the teacher to explain the grammar in the Indonesian language. Unfortunately, the teacher confirmed the difficulty of learning grammar that should be faced by the sixth graders. She stated that they should pay attention to the explanation. If they did not understand about the simple present tense, they would not get the idea of simple past tense.

Unfortunately, the teacher concerned too much on the importance of understanding the grammatical rules in her teaching. Moreover, she tended to use technical terms such as subject, verb 1, verb 2, adverbial time, and pronoun. It is not in line with Sitorus who does not recommend the technical term 
usage in English learning. ${ }^{25}$ Although the six graders are in the highest stage in Elementary school, it does not mean that they can learn as fluent as adults in learning grammar. Pinter has suggested that "grammar is better taught only if young learners grow older and begin to show interest in language analyses. ${ }^{26}$ It is suggested that the explanation about grammar can be done only if the learners are curious to know the reason behind the rule. In fact, the teacher deliberately taught grammar without acknowledging and getting the students' interest first.

Although sixth graders can be considered as older children, the teacher cannot consider them as same as adult learners who can learn grammar explicitly. Grammar should help young learners to deliver a meaningful language. As has been stated before, Brown believes if grammar becomes the main focus in the teaching and learning process, it may hinder the learners to acquire the language. ${ }^{27}$ Besides, young learners have a short span of attention. If there is too much grammar explanation during teaching, they will get bored. Thus, the teacher should be wise in designing the activities for teaching grammar. Forcing young learners to focus on form too much will make them bored and demotivated. Moon assures that the bored and demotivated young

${ }^{25}$ Sitorus, Teaching Grammar to Young Learners.

${ }^{26}$ Pinter, Children Learning Second Languages.

27 Brown, Teaching by Principles: An Interactive Approach to Language Pedagogy. learners will not be successful in learning as they tend to react based on their feelings. ${ }^{28}$ If they are demotivated because of grammar, they will end up hating to learn English. It will give bad impact on their English ability in the future. This is what can happen if the teacher does not adjust the grammar teaching to the young learners' characteristics.

\section{Teaching Grammar Method for Young Learners}

Grammar can be taught using various methods. Based on the observation in the sixth graders' classes, it was found that the teacher taught the grammar to the students separately or in isolation. Once she came up to introduce the tenses, she began her talk by teaching the rule first and finally discussing a passage as the context. It seemed that the students found difficulty in comprehending what the teacher explained. They looked confused once the teacher asked whether they understood her explanation. They felt demotivated and requested the teacher to explain in the Indonesian language. Their confusion ends when a smart student explained her understanding in the Indonesian language.

Pinter states that 'teaching grammar in isolation can be a dry and boring activity'. ${ }^{29}$ In fact, the activities in the class were mainly covered by the teacher talk aimed for explaining the

\footnotetext{
${ }^{28}$ Moon, Children Learning Eng.

${ }^{29}$ Pinter, Children Learning Second Languages.
} 
grammar. The students were only asked to pay attention to. According to Moon, it was not suitable with young learners who are active verbally, physically, and cognitively. Besides, students like to have fun. ${ }^{30}$ Logically, if they have fun and enjoy the learning activities, they will develop a positive attitude towards English. It will lead to greater participation to practice English and continue to achieve the learning goals. Moreover, young learners are those who react based on feeling. If they are happy and secure, they are more likely to enjoy and benefit from their language learning. In fact, those requirements were not found during the observation. They were confused and demotivated. Thus, it is reasonable if the learners did not understand the teacher's explanation.

A phenomenon of having demotivated students in young learners' classroom may happen anytime. It might happen because the activities are not meaningful for the learners. It has been proved during the class observation. The students of the two participants showed their confusion. Other students sitting at the back chose to be busy with their stuffs. There were only smart students who sat down in the front line who participate actively during the explicit grammar learning. They may get excited as their competence is good enough to understand. Others were confused and ended up with feeling uninterested as

${ }^{30}$ Moon, Children Learning Eng. they found that explicit grammar learning is boring and not meaningful to them.

Thus, teaching grammar in young learners' classroom should not be in isolation. Pinter suggests that grammar should be taught in a holistic way. ${ }^{31}$ Rather than teaching grammar in isolation, it might be better to introduce grammar using meaningful activities. Meaningful activities work on young learners since Moon states that one of the young learners' characteristics is going for meaning. ${ }^{32}$ In each activity, they will investigate the meaning first so it can make sense for them.

Actually, it had been good already that in the pre-activityy, the discussion of the topic which was about public places went well. The students were so enthusiastic to answer the questions from the teacher as they were familiar with the topic. Besides, there were supporting materials such as pictures that were drawn in the textbook. It leads to an interesting topic to discuss. It proves Moon who states that if young learners are engaged in interesting activities, they will have a powerful desire to communicate. ${ }^{33}$ It had been meaningful for the learners.

Unfortunately, the teacher did not link that meaningful discussion to the next activity which was the introduction of simple past tense. She ended up the discussion about public places and continued to teach grammar in isolation

\footnotetext{
${ }^{31}$ Pinter, Children Learning Second Languages.

${ }^{32}$ Moon, Children Learning Eng.

${ }^{33}$ Moon.
} 
without bringing the context (public places) that they had discussed before. She directly compared the tenses they wanted to learn that day (simple past tense) to the tenses they had learnt before (simple present tense). Although they had known about Present Tense, it does not guarantee that they will understand Past Tense easily. The technique of comparing tenses did not seem meaningful to the learners. It merely led into confusion. It can be seen at the practice. At that time, the teacher asked the students to change the past form in the passage of report text into the form of present tense. As a result, the students who were pointed to do the task could not do it successfully. In fact, there was a student who was confused about the difference between present tense and past tense. He did not get the point so he only changed the verb without changing the adverbial of time.

According to Moon, young learners tend to go for meaning. ${ }^{34}$ Thus, instead of paying attention to the form, it is better to focus on meaning first. Therefore, rather than comparing the grammatical rules between past and present tense, it may be better if the teacher designs meaningful activities. She can make the use of the discussion about public places to introduce simple past tense. According to Cameron, talking about something meaningful, with young learners can be a useful way to introduce new grammar. Thus, it is

${ }^{34}$ Moon suggested for the teacher teaching grammar to work from a discourse. ${ }^{35}$ It can be in the form of language of classroom management and/ or talking with children. As an example, a teacher can lead the discussion about which places they had visited before and when it was. She might highlight the learners' answers about where and when they had visited and revised them into past form to introduce how to say something that had happened in the past. Here, she can introduce the importance of simple past tense by using the model that she made with the learners.

In fact, instead of applying meaningful activities for teaching grammar, both of the participants chose to have explicit grammar learning in class. Based on the interview, having explicit grammar teaching as one of the focus of discussion in class was their decision as the final exam was approaching. They should have a better understanding of grammar pattern so they can do the exam successfully. Besides, that understanding may be useful for them to perform better in Junior High School, as there would be many exercises on tenses discussed further. Thus, the participants wanted to give the students a basic understanding. At the same time, they should realize that young learners' grammar teaching method is different from the adults' one. The teacher should connect the grammar to the real-world first to ease

35 Cameron, Teaching Languages to Young Learners. 
them understanding the grammar. Thus, it could not be done by discussing the grammar pattern and practicing grammar exercises. Pinter says regarding to Piaget's theory, young learners can only use the rules of formal logic if it is applied to concrete examples and objects in real life. ${ }^{36}$ It is also supported by Brown who suggests that grammar should be contextualized in meaningful language use. ${ }^{37}$ That is why grammar can not be taught explicitly in young learners' class. As the result, confusion happened when the teacher explained the grammar pattern in class. Therefore, it can be concluded that having explicit grammar teaching in young learners' classroom is not a good idea.

\section{The Stages in Teaching Grammar for Young Learners}

Based on the observation, the grammar was taught directly. Meanwhile, Batstone in Cameron proposes to have a noticing stage as the first stage in grammar teaching. ${ }^{38}$ In this stage, the students focus on meaning and take a view on its grammar. It is expected that the students are aware of the structure and they may notice a connection between form and meaning. Based on the observation, the teacher did not proceed the noticing stage

\footnotetext{
${ }^{36}$ Pinter, Children Learning Second Languages.

37 Brown, Teaching by Principles: An Interactive Approach to Language Pedagogy.

38 Cameron, Teaching Languages to Young Learners.
}

effectively. Whereas, there was a reading passage which is very good to be used in noticing stage. Unfortunately, the teacher used the reading passage as a practice for the learners. Due to the interview, the teachers use an interesting topic to discuss in the first as a source for the students to learn the vocabularies. They did not really notice that the context available can be explored further and used as the modeling to notice. As Cameron emphasizes the importance of noticing stage as the first stage in grammar learning, the teachers should make the use of the context to teach grammar. ${ }^{39}$ They may build a fun atmosphere first and make the students notice the modeling. According to Pinter, in this noticing stage, besides working from the discourse, the teacher can introduce the form using puppet songs, stories, reading passages and other inputs which are fun for young learners.

The ways the participants of this research promote explicit grammar teaching here should be concerned. Based on the observation, the teacher only focused on practicing the form. She asked the students to modify some sentences of past form into present form. Thus, the learners might get bored with the activity which was not meaningful. According to Batstone in Cameron, this kind of activities actually belongs to the structuring stage. ${ }^{40}$ It is

\footnotetext{
${ }^{39}$ Pinter, Children Learning Second Languages.

40 Cameron, Teaching Languages to Young Learners.
} 
the second step after the noticing stage. In this stage, the teacher brings the new grammar pattern into the learners' internal grammar. Cameron states that it can be done by having controlled practice around the form and meaning such as questionnaire, survey, and quizzes, information gap activities, helping hands, and drills and chant. ${ }^{41}$ It is good for the learners so they can be accustomed to the verb used in the past form. Fortunately, it was noted that during the teaching and learning in class, the teacher gave drilling about verb mastery. Moreover, there was one teacher who applied rewards system during the drilling. Children like competition so it was fun for them. By having these fun activities, they did not realize that they learn from the play.

In fact, it is still not enough yet if the learners have not got chance to produce what they learn. They may learn to understand the pattern but they may not know how to use the language. On the day of observation, it was found that the teachers were running of time since both of them spent a lot of time to keep explaining the material to those who had not understood. Whereas, according to Batstone in Cameron, there should be a procedural stage as the last step in young learners' grammar teaching. ${ }^{42}$ In this stage, it is suggested to have a procedure in which the learners use the form to express meaning. It can be done by designing fun activities through

${ }^{41}$ Cameron.

${ }^{42}$ Cameron. having role play, making crafts, and other meaningful output. In fact, it was not found during the observation. Due to the limited time, the sixth graders only experience the two first stages. Unfortunately, those two stages did not seem to work smoothly on the learners. No production stage in grammar teaching may hinder the process of achieving its goals. According to the Nation in language learning, an input should be balanced with output. ${ }^{43}$ The grammar they have learned should be practiced and spoken out too. It has been proven by Renanda by recommending the students to have a production stage as the last phase of learning. ${ }^{44}$ What the students learn should be expressed in spoken and/ or written form to see how far their understanding. It is expected that the students can know how to use the language that they have learnt before. The students will not be able to speak in good grammar if they just simply do the written grammar exercises in class without practice to speak.

\section{Conclusion}

After observing the English class of six graders and interviewing the teachers, it is concluded that the

\footnotetext{
43 Paul Nation, 'The Four Strands', Innovation in Language Learning and Teaching 1, no. 1 (16 April 2007): 2-13, https://doi.org/10.2167/illt039.0. 44 Willy A. Renandya. The role of input- and output-based practice in ELT. In A. Ahmed, M. Hanzala, F. Saleem \& G. Cane (Eds.), ELT in a changing world: Innovative approaches to new challenges. Newcastle: Cambridge Scholars Publishing. 2013..
} 
teachers tend to teach grammar explicitly to the six graders. They consider that grammar is important for young learners' language development as it builds the students' grammar awareness. The teachers expect that the students can produce language effectively. Acknowledging that grammar is important to be introduced to young learners, the teachers directly burdened the learners by focusing on form. It made the students find the learning not meaningful. As the consequence, the students got confused as what was found in the observation.

Actually, teachers should design the materials wisely by considering the characteristics of young learners. They should have realized that teaching young learner is different from teaching adult, especially teaching grammar. Although six graders students are considered as those who could use logical thinking as they are older than students from other classes in Elementary school, it does not mean that they are ready to learn English grammar explicitly only. To make it worth- doing, grammar teaching should be meaningful first. It should not be taught in isolation but it should be in a holistic way. It is suggested that the teacher is allowed to explain the grammatical rule if the learners are interested to know the grammatical rule deeper.

Ideally, there should be three meaningful stages in teaching grammar to young learners namely noticing stage, structuring stage, and proceduralizing.
Those stages should be equipped with fun and meaningful activities that lead the students to have a positive attitude toward English. As a result, they are willing to participate in achieving the goals of grammar teaching. Knowing this finding, the teachers should reflect on their grammar teaching method. Moreover, the special characteristics owned by young learners should be involved as the basic consideration in teaching grammar. Hopefully, in the future, the teachers could use these findings as to the consideration for planning their lesson in class. The schools may also support the learning by providing teachers with training so they can have various teaching activities to combine both grammar teaching in the explicit and implicit method.

\section{References}

Ary, Donald, Lucy Cheser Jacobs, Christine K. Sorensen Irvine, and David Walker. Introduction to Research in Education. 10th ed. Boston: Cengage Learning, 2018.

Brown, H. Douglas. Teaching by Principles: An Interactive Approach to Language Pedagogy. 2nd ed. San Fransisco: Longman, 2007.

Cameron, Lynne. Teaching Languages to Young Learners. Cambridge: Cambridge University Press, 2001. 
Garrett, Lisa. 'Teaching Grammar in an English as a Foreign Language (Efl) Context'. The Australian Journal of Indigenous Education 31 (2003): 35-40. https://doi.org/10.1017/S1326011 100003677.

Harmer, Jeremy. How to Teach English. London: Pearson Education Limited, 2007.

Hasanah, Henny Uswatun. 'Teaching Grammar Using Pictures'. OKARA: Jurnal Bahasa dan Sastra 9, no. 1 (2015): 103-12. https://doi.org/http:dx.doi.org/10. 19105/ojbs.v9i1.583.

Ibrahim, Nelvia. 'Games for Teaching Grammar to Young Learners'. Indonesian Journal of Integrated English Language Teaching 2, no. 1 (2016): 49-63. http://dx.doi.org/10.24014/ijielt.v2 i1.2366.

Moon, Jayne. Children Learning Eng. Oxford: Macmillan Henneiman, 2000.

Nation, Paul. 'The Four Strands'. Innovation in Language Learning and Teaching 1, no. 1 (16 April 2007): 2-13. https://doi.org/10.2167/illt039.0.

Pinter, Annamaria. Children Learning Second Languages. London: Palgrave Macmillan, 2011.
Renandya, Willy A. The Role of Inputand Output-based Practice in ELT. In A. Ahmed, M. Hanzala, F. Saleem \& G. Cane (Eds.), ELT in a changing world: Innovative approaches to new challenges. Newcastle: Cambridge Scholars Publishing. 2013.

Richards, Jack C., and Willy A. Renandya. Methodology in Language Teaching: An Anthology of Current Practice. Cambridge: Cambridge University Press, 2002.

Sitorus, Deborah. Teaching Grammar to Young Learners. Jakarta: Universitas Pendidikan Indonesia, 2016.

Ummah, S Sumihatul. 'The Effective Teaching Grammar Activities with No Resources'. OKARA: Jurnal Bahasa dan Sastra 7, no. 2 (2013): 14. http://dx.doi.org/10.19105/ojbs.v7 i2.446.

Uysal, Hacer Hande, Mehmet Bardakci, and Gaziantep University. 'Teacher Beliefs and Practices of Grammar Teaching: Focusing on Meaning, Form, or Forms?' South African Journal of Education 34, no. 1 (5 February 2014): 1-16. https://doi.org/10.15700/2014121 20943. 